\title{
Tracheostomy Tube
}

National Cancer Institute

\section{Source}

National Cancer Institute. Tracheostomy Tube. NCI Thesaurus. Code C17629.

A 2-inch- to 3-inch-long curved metal or plastic tube that is placed in a surgically created opening (tracheostomy) in the windpipe to maintain patency. 